\title{
Percepatan Alih Fungsi (Konversi) Lahan Pertanian Ke Non Pertanian di Kecamatan Galis Kabupaten Pamekasan
}

\author{
Hossaimah, Slamet Subari \\ Program Studi Agribisnis Fakultas Pertanian Universitas Trunojoyo Madura \\ Email : hossaimah@gmail.com
}

\begin{abstract}
ABSTRAK
Rencana Strategis Kabupaten Pamekasan tahun 2012 - 2032, kecamatan Galis direncanakan menjadi pemukiman perkotaan yang telah memiliki persentase lahan pertanian sebesar $50 \%$. Jika terus terjadi pembangunan yang merelakan lahan pertanian produktif sebagai sasarannya, dikhawatirkan lahan pertanian produktif akan habis. Tujuan penelitian adalah menganalisis perkembangan alih fungsi lahan dari tahun 2006-2016 dan menganalisis hubungan faktor ekonomi, faktor sosial dan peran pemerintah terhadap alih fungsi lahan. Penentuan lokasi dilakukan secara sengaja (purposive). Metode penelitian menggunakan analisis deskriptif dengan pendekatan tabulasi silang chi square. Hasilnya adalah selama tahun 20092015 terjadi perubahan fungsi lahan tegal menjadi pemukiman pada tahun 2011 sebesar 1,46 Ha untuk tempat tinggal, tempat usaha dan layanan umum. Faktor - faktor yang memiliki hubungan dengan alih fungsi lahan yaitu produktivitas lahan; peruntukan lahan, asal lahan, perubahan perilaku, hubungan lahan dengan pemilik; dan pengurusan izin. Saran dari penelitian ini adalah memberikan arahan tentang pentingnya pertanian agar tetap eksis; Penegasan mengenai aturan tata guna lahan batas (land use); Mempersulit izin bagi mereka yang akan mengalih fungsi lahan pertanian ke non pertanian

Kata kunci : Lahan Pertanian, Alih Fungsi, Purposive, Cross Tabs Chi Square.

Acceleration Of Agriculture Land To Non Agriculture Land Convertion In Galis District Pamekasan Regency

\section{ABSTRACT}

Strategy Planning Pamekasan Regency year 2012 - 2032 Galis District is going to be city settlement that have $50 \%$ agriculture land. If the construction development of settlement use the productive agriculture land, it worried the productive agriculture land will be used up. The purpose of this research are analyse the development of land conversion from year 2006-2016 and analyse the relation of economic factor, social factor and government's role to land conversion. The determine of location is purposive. The research method use descriptive analyse by cross tabs chi square approach. The results, For about year 2009-2015, land conversion have changed from dry land cultivation to be settlement in year 2011 at 1,46 Ha that used to be house, bussiness place and public place. relation factors to land conversion are land productivity, used of land, history of land, changed of behavior, correlation land with owner and arrangement license. The suggestion, government need to give guidelines about the importance of agriculture; Affirmation at rule in using agriculture land and nonagriculture land limit and make difficulties in giving land conversion license.
\end{abstract}

Key words : Agriculture Land, Convertion, Purposive, Cross Tabs Chi Square

\section{PENDAHULUAN}

Pertambahan penduduk meningkatkan kebutuhan pangan dan pemukiman sehingga terjadi persaingan antara lahan pertanian dan non pertanian. Permasalahannya adalah jumlah luas lahan yang diperebutkan adalah tetap. Untuk mengatasi hal tersebut telah terdapat teori pemanfaatan lahan Von ThÜnen sebagai pertimbangan untuk penggunaan lahan secara efektif menggunakan nilai pemanfaatan tanah (land-Rent) dengan pasar sebagai pusat kegiatan. Teori ini menyatakan bahwa semakin dekat jarak lahan dengan 
Agrisaintifika

Jurnal Ilmu-Ilmu Pertanian

Vol. 1, No. 2, 2017

Hossaimah \& Subari. 2017

pusat kegiatan (pasar) maka semakin mahal nilai sewa tanah (land Rent) tersebut. Wahyunto (2009) menyatakan bahwa meningkatnya jumlah penduduk dan bertambahnya kebutuhan akan lahan untuk berbagai sektor, menyebabkan terjadinya konversi lahan sawah cenderung meningkat, sedangkan pencetakan lahan sawah baru (ekstensifikasi) mengalami perlambatan. Ironisnya tanah yang mengalami alih fungsi adalah tanah yang paling subur di Indonesia yaitu tanah di Pulau Jawa yang merupakan lumbung padi bagi Indonesia.

Konversi lahan tidak hanya terjadi di Pulau Jawa saja, namun juga terjadi di Pulau Madura yang juga merupakan bagian dari Provinsi Jawa Timur. Dari 4 Kabupaten di Madura, salah satu kabupaten yang melakukan konversi lahan adalah kabupaten Pamekasan. Berikut data tentang penggunaan lahan berdasarkan kecamatan di Kabupaten Pamekasan pada tabel 1. Kecamatan Galis memiliki persentase penggunaan lahan non pertanian dan pertanian sebesar $50 \%$, berarti bahwa luas lahan pertanian terendah dimiliki oleh kecamatan Galis.

Rencana Strategis (Renstra) kabupaten pamekasan tahun 2012 - 2032, kecamatan Galis direncanakan dan diprioritaskan menjadi pemukiman perkotaan karena letaknya yang berdekatan dengan pusat pemerintahan yaitu $9,1 \mathrm{~km}$. Dengan adanya rencana ini maka kecamatan Galis pasti akan mengalami pembangunan menggunakan lahan pertanian yang sudah tinggal $50 \%$. Jika terus terjadi pembangunan dengan merelakan lahan pertanian yang produktif sebagai sasarannya, dikhawatirkan kelak lahan-lahan pertanian produktif akan habis dan hal ini tentunya akan berdampak buruk bagi kelangsungan hidup masyarakat. Tujuan dari penelitian ini adalah (1) Menganalisis perkembangan konversi lahan pertanian ke non pertanian di Desa Galis, Kecamatan Galis Kabupaten Pamekasan. (2) Menganalisis faktor-faktor yang berhubungan dan besar hubungan setiap faktor terhadap konversi lahan pertanian di Kecamatan Galis Kabupaten Pamekasan.

\section{BAHAN DAN METODE}

\begin{tabular}{lllr}
\multicolumn{2}{c}{ Penentuan } & tempat & penelitian \\
dilakukan & secara & sengaja & (purposive \\
methods). & Daerah yang & dipilih adalah \\
Kecamatan & Galis dengan & pertimbangan \\
Kecamatan & Galis & memiliki & perbandingan
\end{tabular} lahan pertanian dan non pertanian sebesar $50 \%$. Waktu penelitian pada Bulan Maret 2017 dengan menggunakan data primer dan data sekunder. Data primer diperoleh melalui wawancara menggunakan kuisioner sedangkan data sekunder diperoleh dari instansi terkait dan literatur yang mendukung penelitian ini. Populasi penelitian adalah pemilik lahan pertanian yang telah mengonversi lahan pertanian. Jumlah populasi tidak diketahui karena memang tidak ada data mengenai pemilik lahan pertanian yang melakukan alih fungsi lahan pertanian. Penentuan sampel menggunakan teknik purposive sampling yaitu pemilihan sampel dilakukan secara sengaja dengan pertimbangan responden memiliki lahan yang pernah ditanami padi dan berada di sekitar jalan provinsi dan / atau jalan kabupaten dan telah mengonversi lahan pertanian. Responden yang akan diambil sebanyak 30 responden. Penentuan ini sesuai dengan jumlah sampel minimal dalam penelitian jika jumlah populasi tidak diketahui menurut Roscoe dalam Sugiyono (2007).

Analisis deskriptif dengan menjelaskan hasil penghitungan melalui tabulasi silang (cross tabs chi square) digunakan untuk menjawab penelitian yang pertama yaitu mengetahui hubungan faktorfaktor penentu alih fungsi lahan pertanian dan besarnya faktor-faktor penentu alih fungsi lahan terhadap luas lahan yang dialihfungsi di Kecamatan Galis. Analisis deskriptif digunakan untuk menjawab tujuan penelitian kedua, yaitu menjelaskan perkembangan alih fungsi lahan pertanian ke non pertanian (sawah irigasi dan non irigasi serta pekarangan / bangunan) dari data yang memiliki rentang waktu selama 10 tahun yaitu periode 2006-2016 di kecamatan Galis.

\section{Analisis Chi Square}

Gibbon (1975) menyatakan bahwa analisis Chi Square merupakan alat analisis 
yang digunakan untuk mengetahui adanya hubungan antara variabel dependen dengan variabel independen. Untuk menguji analisis Chi-Square dapat menggunakan program SPSS 13 dengan dasar pengambilan keputusan dapat menggunakan nilai $X^{2}$ hitung yang dibandingkan dengan $x^{2}$ tabel dan dengan menggunakan nilai Asymp Sig yang dibandingkan dengan nilai $\alpha$. Dasar pengambilan keputusannya adalah bila menggunakan $X^{2}$ tabel yaitu jika nilai $X^{2}$ hitung $>X^{2}$ maka menerima $\mathrm{H}_{1}$ dan menolak $H_{0}$. Apabila menggunakan nilai Asymp Sig yang dibandingkan dengan $\alpha$ maka dasar pengambilan keputusan adalah jika nilai Asymp Sig > a maka menerima $\mathrm{H}_{1}$ dan menolak $\mathrm{H}_{0}$. Dalam penelitian ini hipotesis yang digunakan adalah:

$\mathrm{H} 0$ :Tidak terdapat hubungan yang signifikan antara faktor-faktor yang diduga memiliki hubungan dengan besar luas konversi lahan.

$\mathrm{H} 1$ :Terdapat hubungan yang signifikan antara faktor-faktor yang diduga memiliki hubungan dengan besar luas konversi lahan.

\section{HASIL DAN PEMBAHASAN}

\section{Perkembangan Alih Fungsi Lahan di Kecamatan Galis}

Kecamatan

Galis

merupakan

kecamatan di Kabupaten Pamekasan yang memiliki lahan pertanian dengan persentase penggunaan lahan pertanian paling kecil yaitu $50 \%$ pada tahun 2015. Perbandingan ini selain disebabkan oleh jenis tanah di Kecamatan Galis yang sebagian besar merupakan tanah bukan pertanian juga karena adanya alihfungsi dari lahan pertanian ke non pertanian. Pada tabel 2 menyajikan data dari tahun 2009-2015 karena keterbatasan data selama penelitian berlangsung sehingga penggunaan lahan yang dapat dijabarkan hanya 7 tahun. Pada data tersebut terlihat peningkatan jumlah luas pemukiman pada tahun 2011 sebesar 1,46 Ha dan pada tahun yang sama juga terjadi penurunan luas tegal sebesar 1,45 $\mathrm{Ha}$. Jadi menurut data sekunder pada tahun 2011 terjadi alih fungsi lahan sebesar 1,45 Ha dari lahan tegal menjadi pemukiman. Hasil pengumpulan data di lapang selama tahun tersebut terjadi alih fungsi lahan menjadi pemukiman sebesar $1317 \mathrm{~m}^{2}$. Pada tahun tahun sebelumnya terjadi alih fungsi lahan menjadi lapangan, poskesdes, pemukiman dan warung. Di data BPS untuk tahun 20132015 tidak terjadi alih fungsi lahan. Selama tahun 2013- 2015 tidak dapat dijabarkan luas masing-masing penggunaan lahan untuk pemukiman, kuburan, dan lainnya seperti periode tahun 2009 - 2012 karena terdapat perubahan format penulisan pada buku Badan Pusat Statistik yang dapat dilihat pada Tabel 3.

Dari hasil wawancara kepada responden diketahui bahwa alih fungsi lahan pertanian yang terjadi selama tahun 20082016 di kecamatan Galis sebesar $19981 \mathrm{~m}^{2}$ dengan masing-masing luas lahan pada tabel 4. Lahan pertanian yang telah dialihfungsi digunakan untuk tempat tinggal sebesar $47 \%$, hal ini disebabkan oleh pertambahan jumlah keluarga yang mengharuskan mereka membuat rumah, tempat usaha $43 \%$ dan layanan umum 10\%. Tempat usaha dialih fungsi menjadi toko, warung makan, kolam renang, kolam lele dan kandang. Masyarakat mengalih fungsi lahan karena mereka ingin mendapatkan penghasilan lebih banyak dari pada mengolah lahan pertanian. Sedangkan untuk layanan umum dialih fungsi menjadi lapangan, poskesdes, pasar dan jalan karena memang kebutuhan masyarakat. Hasil penghitungan dapat dilihat pada tabel 5 .

Sebenarnya pada tahun-tahun yang dinyatakan tidak terdapat perubahan alih fungsi lahan dari data sekunder dapat dikemukakan 3 kemungkinan. Yang pertama yaitu terjadi alih fungsi lahan namun tidak terdaftar karena wilayah yang mengalami alih fungsi lahan sempit sehingga tidak terdeteksi, kedua adalah pemilik lahan yang mengalih fungsi lahan tidak mengurus izin sehingga data tidak masuk ke dinas pertanahan yang menyebabkan data tidak masuk ke BPS dan yang ketiga adalah memang tidak terjadi alih fungsi lahan (Sunartomo,2015). 
Agrisaintifika

Jurnal Ilmu-Ilmu Pertanian

Vol. 1, No. 2, 2017

Hossaimah \& Subari. 2017

Faktor - Faktor yang Berhubungan dengan Alih Fungsi Lahan Pertanian

Alih fungsi lahan pertanian merupakan

suatu hal yang tidak dapat dihentikan karena kebutuhan akan pemukiman dan prasarana lainnya merupakan kebutuhan yang penting. Selain itu pertumbuhan penduduk juga mengakibatkan kebutuhan pangan juga meningkat. Yang menjadi permasalahan adalah kebutuhan pangan dan kebutuhan pemukiman serta prasarana lainnya sama-sama membutuhkan lahan yang luasnya tetap sehingga terjadi persaingan lahan untuk memenuhi kebutuhan makan dan tempat tinggal. Pada saat ini lahan yang biasa digunakan untuk ditanami padi semakin tersingkirkan dengan adanya alih fungsi menjadi bangunan. Banyak faktor yang menjadi penyebab terjadinya alih fungsi lahan tersebut. Tiga faktor yang akan diuraikan dalam pembahasan ini diduga berhubungan dengan alih fungsi yang dilakukan oleh pemilik lahan pertanian yang sebelumnya pernah ditanami padi menjadi non pertanian di Kecamatan Galis. Ketiga faktor tersebut yaitu faktor ekonomi, faktor sosial, dan peran pemerintah yang akan dijabarkan sebagai berikut :

\section{Faktor Ekonomi}

Faktor ekonomi diwakili oleh beberapa indikator yaitu jarak dari jalan raya provinsi dan jalan kabupaten, harga lahan, dan produktivitas lahan. Lokasi lahan dengan jalan raya diduga memiliki hubungan terhadap alih fungsi lahan. Menurut teori Von Thunen, semakin dekat lokasi tanah dengan pusat kota yang merupakan pusat kegiatan ekonomi maka semakin tinggi nilai landrent-nya (nilai tanah berdasarkan pemanfaatan). (Tarigan, 2015). Dalam hal ini kedekatan lahan dengan jalan raya juga menyebabkan nilai land-rent-nya semakin tinggi karena semakin mudah para petani mengangkut hasil panen mereka ke kota. Di Kecamatan Galis, alih fungsi lahan terjadi pada lahan yang dekat dengan jalan raya dengan luas alih fungsi lahan yang sempit (rendah). Berikut tabel 6 hasil penghitungan alih fungsi lahan berdasarkan letak/jarak dengan jalan raya.

Pembagian kelas/nilai dari alih fungsi lahan yaitu menggunakan pengkategorian. Diketahui bahwa nilai luas alih fungsi lahan tertinggi yaitu $2450 \mathrm{~m}^{2}$ dan terendah yaitu $70 \mathrm{~m}^{2}$. Dari selisih kedua nilai tersebut kemudian dibagi menjadi 3 kelas yaitu rendah, sedang, tinggi. Alih fungsi rendah merupakan besar luas lahan yang dialih fungsi yang berada dalam rentang 70$863,3 \mathrm{~m}^{2}$, alih fungsi lahan sedang merupakan luas alih fungsi lahan yang memiliki luas dengan rentang 863,3-1656,7 $\mathrm{m}^{2}$ dan alih fungsi tinggi merupakan alih fungsi lahan yang terjadi dari $1656,7-2450 \mathrm{~m}^{2}$. Alih fungsi lahan pertanian sebagian besar $(70 \%)$ terjadi pada jarak yang dekat dengan jalan raya dengan luas lahan yang rendah. Hal ini sesuai dengan teori Von Thunen yang mengemukakan bahwa tanah yang dekat dengan pusat kegiatan (jalan) memiliki nilai sewa tanah / land-rent lebih tinggi sehingga akan lebih efisien jika dimanfaatkan sebagai jasa atau perdagangan karena memiliki daya beli yang relatif tinggi dari pada dimanfaatkan untuk kegiatan pertanian. Hasil penghitungan nilai sig sebesar 0,172 berarti bahwa peluang salah dalam melakukan pendugaan parameter ; hubungan jarak dari jalan raya dengan luas alih fungsi lahan adalah sebesar $17,2 \%$. Berarti bahwa lahan yang dekat dengan jalan raya belum tentu membuat pemilik lahan mengalih fungsi lahan menjadi non pertanian.

Selain jarak, harga diduga memiliki hubungan dengan luas lahan yang akan dialih fungsi oleh petani. Harga lahan yang berlaku terendah sebesar $\operatorname{Rp} 14.000$ dan harga tertinggi adalah $\mathrm{Rp} 300.000$. Harga dikategorikan menjadi 2 kelas yaitu murah dan mahal, langkah pengkategorian yaitu seperti pengkelasan pada luas alih fungsi lahan. Informasi harga ini diperoleh melalui Nilai Jual Objek Pajak (NJOP) pada kartu bukti pembayaran pajak dan tafsiran dari pemilik apabila lahan akan dijual. Dalam penentuan lahan, harga juga dipengaruhi oleh keadaan penjual. Ketika penjual sangat membutuhkan dana cepat maka penjual akan menemui pembeli yang dapat segera memenuhi kebutuhannya tanpa mempedulikan taksiran harga. Tabel 7 menunjukan hasil 
penghitungan harga lahan terhadap besar luas alih fungsi lahan.

Dari penghitungan tersebut diketahui bahwa alih fungsi lahan di Kecamatan Galis terjadi pada lahan yang memiliki harga yang murah dengan luas lahan yang rendah. Hasil penghitungan nilai sig sebesar 0,799 yang berarti bahwa 79,9\% dari responden mengalih fungsi lahannya bukan karena harganya yang mahal. Hal ini disebabkan oleh subyek yang melakukan alih fungsi lahan adalah pemilik lahan sendiri yang membutuhkan tempat tinggal dan melakukan usaha lain seperti membuka toko, membuat kolam renang, mebel, dengan harapan dapat meningkatkan pendapatan. Teori Von thunen sesuai dengan fakta di lapang yang menyatakan bahwa semakin dekat lahan dengan pusat kegiatan (jalan) maka nilai land-rent-nya semakin tinggi. Namun meskipun demikian, dalam kasus ini harga tidak menjadi penyebab terjadinya alih fungsi lahan karena subyek dari pelaku alih fungsi adalah petani, bukan perusahaan. Pemilik lahan tidak menjual lahan untuk dialih fungsi ke perusahaan untuk kegiatan industri melainkan dijadikan tempat tinggal dan usaha. Benu et. al (2013) menyatakan bahwa terdapat 2 tipe proses konversi lahan pertanian, yaitu konversi lahan secara langsung oleh petani dan non petani yang melakukan proses penjualan. Dalam hal ini maka tipe proses alih fungsi lahan di kecamatan Galis adalah konversi lahan secara langsung. Hasil penghitungan ini berbeda dengan hasil penelitian yang dilakukan oleh Kurniasari, et.al (2014) yang menyatakan bahwa rasio harga lahan berpengaruh terhadap jumlah konversi lahan, hal ini karena penelitian yang dilakukan oleh Kurniasari petani cenderung menjual tanahnya kepada perusahaan / orang lain untuk dialihfungsi sedangkan di Kecamatan Galis alih fungsi lahan dilakukan oleh petani sendiri menjadi pemukiman atau tempat usaha.

Indikator ketiga yaitu produktivitas lahan merupakan kemampuan lahan untuk memproduksi padi pada setiap meter persegi $\left(\mathrm{kw} / 100 \mathrm{~m}^{2}\right)$. Di Kecamatan Galis, alih fungsi lahan terjadi di lahan yang memiliki produktivitas rendah $\left(1,4-1,8 \mathrm{kw} / 100 \mathrm{~m}^{2}\right)$, sedang $\left(1,8-2,5 \mathrm{kw} / 100 \mathrm{~m}^{2}\right)$ dan tinggi $(2,5-$ $\left.3,0 \mathrm{kw} / 100 \mathrm{~m}^{2}\right)$.

Dari ketiga kategori pada Tabel 8 diketahui bahwa alih fungsi lahan pertanian terbanyak terjadi pada lahan yang memiliki produktivitas rendah. Semakin rendah produktivitas lahan dan semakin sempit luas lahan menyebabkan petani mengalih fungsi lahan pertanian. Nilai sig sebesar 0.00 menyatakan bahwa seluruh responden yang mengalih fungsi lahan pertanian memiliki lahan yang sempit dengan produktivitas rendah. Hasil penghitungan ini memiliki kesamaan dengan hasil penelitian yang dilakukan oleh Firmansyah, et. al. (2013) yang menyatakan bahwa salah satu faktor yang menyebabkan petani di Kabupaten Gresik mengalih fungsi pertanian adalah produktivitas lahan yang semakin rendah. Apabila rendahnya produktivitas ini tidak ditangani, menyebabkan pemilik lahan mengalih fungsi lahan pertanian sehingga perlu adanya teknologi untuk meningkatkan produksi pada kondisi lahan yang memiliki produktivitas rendah tersebut. Selain itu, penerapan teknologi juga perlu dilakukan oleh para petani dan diperlukan peran penyuluh pertanian memperkenalkan teknologi sehingga petani mau mengimplementasi teknologi untuk meningkatkan produktivitas lahan.

\section{Faktor Sosial}

Faktor sosial diwakili oleh indikator asal lahan, pemecahan lahan, perubahan perilaku dan hubungan pemilik lahan dengan pengolah lahan. Indikator pertama merupakan asal lahan untuk dialih fungsi. Lahan warisan diperoleh dari orang tua yang sudah mengolah lahan pertanian yang ditanami padi, namun karena pertambahan jumlah anggota keluarga menyebabkan masyarakat mengalih fungsi lahan. Orang yang membeli lahan digunakan untuk membuka usaha seperti toko, tempat mebel dan kolam renang. Berikut pada Tabel 9 hasil penghitungan asal lahan terhadap alih fungsi lahan di Kecamatan Galis.

Hasil penghitungan tersebut diketahui bahwa $60 \%$ lahan yang dialih fungsi 
Agrisaintifika

Jurnal Ilmu-Ilmu Pertanian

Vol. 1, No. 2, 2017

Hossaimah \& Subari. 2017

merupakan lahan sempit dan berasal dari warisan. Nilai sig sebesar 0,0001 berarti bahwa peluang salah dalam melakukan pendugaan parameter ; hubungan produktivitas dengan luas alih fungsi lahan adalah sebesar $0,01 \%$. Lahan yang berasal dari pemerintah digunakan untuk layanan umum. Indikator kedua adalah pemecahan lahan yaitu keputusan pemilik lahan untuk mengalih fungsi lahan yang disebabkan oleh semakin sempitnya warisan yang diperoleh sehingga jika diolah sebagai lahan pertanian hasilnya rendah. Bertambahnya jumlah anggota keluarga yang menempati rumah menyebabkan terjadinya alih fungsi lahan. Berikut pada Tabel 10 hasil penghitungan pemecahan lahan terhadap alih fungsi lahan. Dari tabel tersebut diketahui bahwa luas alih fungsi lahan terjadi pada kategori rendah dengan $60 \%$ bukan karena hasil warisan yang menyempit. Hasil penghitungan nilai sig yaitu 0,135 berarti bahwa peluang salah dalam melakukan pendugaan parameter ; hubungan pemecahan lahan dengan luas alih fungsi lahan adalah sebesar 13,5\%.

Indikator ketiga yang diduga menjadi faktor penyebab terjadinya alih fungsi lahan adalah perubahan perilaku. Perubahan perilaku dapat terjadi karena adanya sarana komunikasi dan sarana transportasi yang memadai sehingga terbukanya wawasan baru bagi penduduk desa tentang lingkungan di luar. Berikut tabel 11 hasil penghitungan perubahan perilaku terhadap alih fungsi lahan di Kecamatan Galis. Perubahan perilaku terjadi pada alih fungsi lahan yang rendah. Jadi dapat dikatakan bahwa perubahan perilaku memiliki hubungan dengan luasnya alih fungsi lahan. Hasil penghitungan nilai sig diperoleh nilai sebesar 0,05 berarti bahwa peluang salah dalam melakukan pendugaan parameter ; hubungan perubahan perilaku dengan luas alih fungsi lahan adalah sebesar 5\%. Pendapat masyarakat di Kecamatan Galis yang telah mengalih fungsi lahan pertanian menyatakan bahwa pekerjaan petani bukanlah pekerjaan yang ketinggalan zaman, namun separuh atau $50 \%$ dari responden yang memiliki lahan pertanian yang telah dialihfungsi lebih memilih mengalih fungsi lahan kemudian dijadikan warung makan, toko atau meminta orang lain untuk mengerjakan sawah miliknya karena pemilik lahan memiliki pekerjaan lain seperti sopir, PNS, dan wiraswasta.

Hasil penghitungan ini sesuai dengan pernyataan Sunartomo (2015) dalam penelitiannya yang menyebutkan bahwa gencarnya alih fungsi lahan tidak hanya disebabkan oleh tidak efektifnya peraturan perundang-undangan baik dari ketentuan yang tidak jelas dan tegas maupun penegakan yang tidak didukung oleh pemerintah sendiri. Namun juga didukung oleh sektor pertanian yang dianggap "tidak menarik", harga pupuk serta alat produksi yang mahal dan langka, tenaga kerja yang semakin sedikit serta harga produk pertanian yang fluktuatif dan cenderung menurun sehingga hal ini mengakibatkan minat penduduk atau sekedar hanya mempertahankan fungsi lahannya menurun. Dari permasalahan tersebut,perlu adanya peran pemerintah untuk tetap menjaga perilaku petani untuk bertani dengan memberikan arahan pada mereka tentang pentingnya keeksisan lahan pertanian dalam pemenuhan kebutuhan pangan.

Bagi pemilik lahan yang memang sebagai petani dimana lahan merupakan sumber penghasilan untuk bertahan hidup akan mengolah sendiri lahan yang dimiliki sebelum lahan dialih fungsi. Pemilik lahan tidak mengolah sendiri lahan yang dimiliki karena adanya pekerjaan lain dan cenderung memberikan lahan kepada orang yang masih memiliki ikatan keluarga yang bekerja sebagai petani untuk diolah. Kemudian untuk hasil panen dibagi sesuai dengan kesepakatan antara pemilik dengan pengolah lahan. Berikut tabel 12. hasil penghitungan besarnya alih fungsi lahan terhadap hubungan pemilik menggunakan analisis chi square.

Dari hasil penghitungan, diketahui bahwa alih fungsi terjadi pada lahan yang memiliki hubungan / ikatan keluarga sebesar $57 \%$ sedangkan untuk $43 \%$ lainnya terjadi pada lahan yang tidak terdapat hubungan. Hal ini dapat dikatakan bahwa peluang salah dalam melakukan pendugaan parameter ; hubungan pemilik dengan luas alih fungsi lahan 
Agrisaintifika

Jurnal Ilmu-Ilmu Pertanian

Vol. 1, No. 2, 2017

Hossaimah \& Subari. 2017

adalah sebesar $2 \%$.

\section{Peran pemerintah}

Variabel berikutnya yaitu peran pemerintah yang merupakan ada atau tidaknya peran pemerintah untuk melarang pemilik lahan mengalih fungsi lahannya. Hal ini dilihat dari pemberian izin pada masyarakat yang mengalih fungsi lahan. Berikut Tabel 13 hasil penghitungan pengurusan izin terhadap terjadinya alih fungsi lahan pertanian ke non pertanian di Kecamatan Galis. Fakta di lapang menunjukkan bahwa $57 \%$ responden mengurus izin untuk mengalih fungsi lahan pertanian ke non pertanian sedangkan $43 \%$ tidak mengurus izin. Hal ini dapat dikatakan bahwa untuk mengalih fungsi lahan pertanian terdapat peran pemerintah sebesar 57\%. Hasil dari penghitungan diperoleh nilai sig sebesar 0,020 yang artinya bahwa peluang salah dalam melakukan pendugaan parameter ; hubungan pengurusan izin terhadap luas alih fungsi lahan adalah sebesar $2 \%$. Izin yang diurus yaitu berupa izin mendirikan bangunan untuk lahan yang dialih fungsi menjadi rumah, izin melakukan usaha untuk lahan yang didirikan toko, izin lingkungan ketika lahan dialih fungsi manjadi kolam renang dan kandang yang nantinya menghasilkan limbah dan dapat mengganggu lingkungan. Ketika masyarakat mengurus izin kepada pemerintah tidak terdapat suatu larangan atau himbauan agar tidak mengalih fungsi lahan karena pemerintah merasa itu wajar saja dan menjadi hak mereka karena lahan tersebut merupakan hak pemilik lahan untuk dijadikan apapun. Hal yang sama terjadi pada hasil penelitian yang dilakukan oleh Trinasari, et.al (2015) di Ciparay, Bandung yang menyatakan bahwa salah satu faktor yang berpengaruh secara signifikan terhadap alih fungsi lahan adalah kebijakan pemerintah yang memberikan izin kepada masyarakat yang mengalih fungsi lahan.

Di Kecamatan Galis masih belum ada larangan untuk mengalih fungsi lahan pertanian. Namun penggunaan lahan telah diatur dalam Peraturan Daerah Kabupaten Pamekasan Nomor 16 tahun 2012 tentang
Rencana Tata Ruang Wilayah Kabupaten Pamekasan 2012-2032 pasal 61. Pada pasal tersebut ditetapkan bahwa kawasan tidak terbangun atau ruang pertanian yang produktif harus dilakukan pengamanan untuk tidak dialihfungsikan menjadi non pertanian dan perubahan fungsi ruang dilakukan pada lahan yang kurang produktif. Di kecamatan Galis hasil penghitungan menunjukkan bahwa alih fungsi lahan terjadi pada lahan yang memiliki produktiitas rendah sehingga sejauh ini alih fungsi masih berjalan sesuai dengan peraturan daerah. Pada peraturan ini wilayah kabupaten Pamekasan dibagi menjadi beberapa kawasan beserta ketetapan luas lahan untuk masing-masing kawasan. Kawasan peruntukan pertanian yang meliputi tanaman pangan $31.733 \mathrm{Ha}$, holtikultura 8.376 Ha, perkebunan $318 \mathrm{Ha}$, peternakan 0 Ha. Kawasan peruntukan perikanan (tambak garam) seluas $2.096 \mathrm{Ha}$. Kawasan peruntukan pertambangan sebesar $4.181 \mathrm{Ha}$, industri $1.271 \mathrm{Ha}$ dan kawasan peruntukan permukiman sebesar $6.271 \mathrm{Ha}$. Luasan ini untuk seluruh wilayah. Kabupaten Pamekasan sedangkan untuk luasan untuk perkecamatan khususnya untuk kecamatan Galis tidak dapat dijabarkan karena keterbatasan data saat penelitian berlangsung, sehingga dengan demikian pembagian pembatasan wilayah antara lahan pertanian dan non pertanian sampai tingkat kecamatan sangat perlu dilakukan agar kebutuhan lahan untuk pertanian dan non pertanian dapat disesuaikan. Selain itu penegakan dari peraturan tersebut juga senantiasa diawasi oleh aparat yang berwenang.

\section{KESIMPULAN}

Simpulan dari hasil penelitian yang berjudul percepatan alih fungsi (konversi) lahan pertanian ke non pertanian di kecamatan galis kabupaten pamekasan yakni perkembangan alih fungsi lahan dari tahun 2009 - 2015 terjadi perubahan fungsi lahan tegal menjadi pemukiman pada tahun 2011 sebesar $1,46 \mathrm{Ha}$ yang digunakan untuk pemukiman, tempat usaha dan layanan umum; Faktor-faktor yang memiliki hubungan terhadap alih fungsi lahan yaitu faktor 
ekonomi pada variabel produktivitas lahan; faktor sosial yaitu pada variabel peruntukan lahan, asal lahan, perubahan perilaku, dan hubungan lahan dengan pemilik; faktor peran pemerintah yaitu pada variabel pengurusan izin yang memiliki nilai hitung sig kurang dari 0,05. Saran dari penelitian ini untuk menghambat percepatan alih fungsi lahan hal yang harus dilakukan oleh pemerintah, yaitu memberikan arahan tentang pentingnya pertanian agar tetap eksis; Penegasan mengenai aturan tata guna lahan batas (land use); Mempersulit izin bagi mereka yang akan mengalih fungsi lahan pertanian ke non pertanian.

\section{DAFTAR PUSTAKA}

Badan Pusat Statistik Kabupaten Pamekasan. 2014. Pamekasan Dalam Angka 2014 Angka 2015

2015. Pamekasan Dalam . 2016. Pamekasan Dalam Angka 2016

. 2010. Kecamatan Galih Dalam Angka 2010

. 2011. Kecamatan Galis Dalam Angka 2011

. 2012. Kecamatan Galis Dalam Angka 2012

. 2013. Kecamatan Galis Dalam Angka 2013

2014. Kecamatan Galis Dalam Angka 2014

2015. Kecamatan Galis Dalam Angka 2015 2016. Kecamatan Galis Dalam Angka 2016

Benu, N,M. Maryunani, Sugiyanto dan Kindangen,P. 2013. Analysis of Land Conversion and its Impacts and Strategies in Managing Them in City of
Tomohon, Indonesia.Asian Transaction on Basic and Applied Sciences (ATBAS ISSN : 2221-429). Vol.03. Issue 02.

Firmansyah, F. dan Purwadio, H. 2013. Arahan Pengendalian Konversi Lahan Pertanian ke Non-Pertanian di Kabupaten Gresik. Jurnal Teknik Pomits. Vol. 2, No. 1.

Kurniasari, M dan Ariastita, P.G. 2014. Faktor Faktor yang Mempengaruhi Alih Fungsi Lahan Pertanian Sebagai Upaya Prediksi Perkembangan Lahan Pertanian di Kabupaten Lamongan. Jurnal Teknik Pomits Vol. 3, No. 2.

Peraturan Daerah Kabupaten Pamekasan. PerDa Kabupaten Pamekasan Nomor 16 Tahun 2012. Rencana Tata Ruang Wilayah Kabupaten Pamekasan 20122032.

Sugiyono. 2007. Statistik untuk penelitian (edisi revisi). Bandung. Alfabeta

Sunartomo, A F.2015. Perkembangan Konversi Lahan Pertanian di Kabupaten Jember. Agriekonomika. Vol 4. No.1

Tarigan, R.2015. Perencanaan Pembangunan Wilayah. Edisi Revisi. PT Bumi Aksara. Jakarta.

Trinasari, D., Sebayang, A.F., Haryatiningsih, R. 2015. Keputusan Rumah Tangga Petani Dalam Alih Fungsi Lahan Pertanian di Desa Bumi Wangi Kecamatan Ciparay Kabupaten Bandung. Prosiding ilmu ekonomi.

Wahyunto. 2009. Lahan Sawah di Indonesia Sebagai Pendukung Ketahanan Pangan Nasional. Jurnal Informatika Pertanian. Vol. 18, No. 2. 
Hossaimah \& Subari. 2017

Tabel 1. Distribusi penggunaan lahan di Kabupaten Pamekasan (Ha)

\begin{tabular}{|c|c|c|c|c|}
\hline \multirow[t]{2}{*}{ No } & \multirow[t]{2}{*}{ Kecamatan } & \multicolumn{3}{|c|}{$\begin{array}{c}\text { Persentase Lahan Pertanian } \\
(\%)\end{array}$} \\
\hline & & Tahun 2013 & Tahun 2014 & Tahun 2015 \\
\hline 1 & Tlanakan & 81 & 81 & 81 \\
\hline 2 & Pademawu & 82 & 82 & 82 \\
\hline 3 & Galis & 50 & 50 & 50 \\
\hline 4 & Larangan & 69 & 69 & 69 \\
\hline 5 & Pamekasan & 65 & 65 & 65 \\
\hline 6 & Proppo & 80 & 80 & 80 \\
\hline 7 & Palengaan & 83 & 83 & 83 \\
\hline 8 & Pegantenan & 75 & 75 & 75 \\
\hline 9 & Kadur & 86 & 86 & 86 \\
\hline 10 & Pakong & 83 & 83 & 83 \\
\hline 11 & Waru & 91 & 91 & 91 \\
\hline 12 & Batumarmar & 92 & 92 & 92 \\
\hline 13 & Pasean & 92 & 92 & 92 \\
\hline
\end{tabular}

Sumber : Badan Pusat Statistik Pamekasan, 2014-2016

Tabel 2. Penggunaan lahan di Kecamatan Galis ( $\mathrm{Ha})$

\begin{tabular}{|c|c|c|c|c|c|c|c|c|c|c|c|}
\hline$\frac{5}{\frac{c}{\frac{1}{\sigma}}}$ & 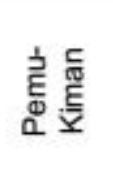 & 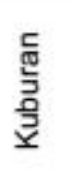 & 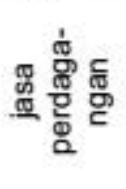 & 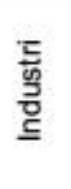 & 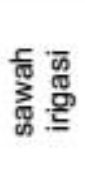 & 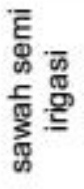 & 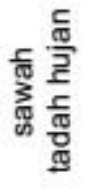 & $\begin{array}{l}\bar{g} \\
\stackrel{\Phi}{\circ}\end{array}$ & $\begin{array}{l}\text { ज్ } \\
\text { בొ }\end{array}$ & 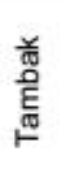 & $\frac{\frac{c}{\omega}}{\underline{E}}$ \\
\hline 2009 & 281,16 & 7,1 & 3,4 & 5,5 & 578 & 72 & 257 & 892,84 & 269 & 820 & 3186 \\
\hline 2010 & 281,16 & 7,1 & 3,4 & 5,5 & 578 & 72 & 257 & 892,84 & 269 & 820 & 3186 \\
\hline 2011 & 282,62 & 7,1 & 3,4 & 5,5 & 578 & 72 & 257 & 891,39 & 269 & 820 & 3186 \\
\hline 2012 & 282,62 & 7,1 & 3,4 & 5,5 & 578 & 72 & 257 & 891,39 & 269 & 820 & 3186 \\
\hline
\end{tabular}

Sumber: Badan Pusat Statistik Pamekasan 2010-2013

Tabel 3. Penggunaan lahan di Kecamatan Galis (Ha)

\begin{tabular}{ccccc}
\hline \multirow{2}{*}{ Tahun } & \multicolumn{2}{c}{ Pertanian } & & \multirow{2}{*}{ Jumlah } \\
\cline { 2 - 3 } & sawah & $\begin{array}{c}\text { bukan } \\
\text { sawah }\end{array}$ & bukan pertanian & 3.186 \\
\hline 2013 & 981 & 618 & 1.587 & 3.186 \\
2014 & 981 & 618 & 1.587 & 3.186 \\
2015 & 981 & 618 & 1.587 & \\
\hline
\end{tabular}

Sumber: Badan Pusat Statistik Pamekasan 2014-2016

Tabel 4. Luas alih fungsi lahan pertanian di Kecamatan Galis (m2)

\begin{tabular}{cccc}
\hline Tahun & Luas alih fungsi & Tahun & \multicolumn{2}{c}{ Luas alih fungsi } \\
\hline 2008 & 4680 & 2013 & 3720 \\
2009 & 730 & 2014 & 1250 \\
2010 & 2850 & 2015 & 650 \\
2011 & 1317 & 2016 & 4784 \\
2012 & - & & \\
\hline \multicolumn{2}{l}{ Total luas alih fungsi tahun 2008-2016 } & & 19981 \\
\hline
\end{tabular}

Sumber : Data primer diolah, 2017 
Hossaimah \& Subari. 2017

Tabel 5. Alih Fungsi Lahan Pertanian Berdasarkan Peruntukan Lahan

\begin{tabular}{lcccc}
\hline \multicolumn{1}{c}{ Alih fungsi } & $\begin{array}{c}\text { Tempat } \\
\text { tinggal }\end{array}$ & $\begin{array}{c}\text { Tempat } \\
\text { usaha }\end{array}$ & $\begin{array}{c}\text { Layanan } \\
\text { umum }\end{array}$ & Total \\
\hline Rendah $(70-863,3)$ & 13 & 11 & 1 & 25 \\
Sedang(863,3-656,7) & 1 & 2 & 1 & 4 \\
Tinggi $(1656,7-2450)$ & 0 & 0 & 1 & 1 \\
\hline Total & 14 & 13 & 3 & 30 \\
\hline Persentase (\%) & 47 & 43 & 10 & 100 \\
\hline
\end{tabular}

Sumber : Data primer diolah, 2017

Tabel 6. Alih Fungsi Lahan Pertanian Berdasarkan Jarak Dengan Jalan Raya (m)

\begin{tabular}{lccc}
\hline \multicolumn{1}{c}{ Alih fungsi $\left(\mathrm{m}^{2}\right)$} & $\begin{array}{c}\text { Dekat }(\mathrm{m}) \\
(2-1001)\end{array}$ & $\begin{array}{c}\text { Jauh }(\mathrm{m}) \\
(1001-2000)\end{array}$ & Total \\
\hline Rendah $(70-863,3)$ & 19 & 6 & 25 \\
Sedang $(863,3-656,7)$ & 2 & 2 & 4 \\
Tinggi $(1656,7-2450)$ & 0 & 1 & 1 \\
\hline Total & 21 & 9 & 30 \\
\hline Persentase (\%) & 70 & 30 & 100 \\
\hline Nilai sig & & & 0,172 \\
\hline
\end{tabular}

Sumber : Data primer diolah, 2017

Tabel 7. Alih Fungsi Lahan Pertanian Berdasarkan Harga (Rp/m2)

\begin{tabular}{lcccr}
\hline \multicolumn{1}{c}{ Alih fungsi $\left(\mathrm{m}^{2}\right)$} & $\begin{array}{c}\text { Murah }(\mathrm{Rp}) \\
(14000- \\
109300)\end{array}$ & $\begin{array}{c}\text { Mahal }(\mathrm{Rp}) \\
(109300- \\
204600)\end{array}$ & $\begin{array}{c}\text { Sangat mahal } \\
(\mathrm{Rp}) \\
(204600-\end{array}$ & Total \\
& 13 & 10 & 2 & 25 \\
\hline Rendah(70-863,3) & 3 & 1 & 0 & 4 \\
Sedang(863,3-656,7) & 1 & 0 & 0 & 1 \\
Tinggi $(1656,7-2450)$ & 17 & 11 & 2 & 30 \\
\hline Total & 56,67 & 36,67 & 0,67 & 100 \\
\hline Persentase $(\%)$ & & & & 0.799 \\
\hline Nilai sig & & & &
\end{tabular}

Sumber : Data primer diolah, 2017

Tabel 8. Alih Fungsi Lahan Pertanian Berdasarkan Produktivitas (kw / 100m2)

\begin{tabular}{lcccc}
\hline \multicolumn{1}{c}{ Alih fungsi $\left(\mathrm{m}^{2}\right)$} & $\begin{array}{c}\text { Rendah } \\
(1,4-1,9)\end{array}$ & $\begin{array}{c}\text { Sedang } \\
(1,9-2,5)\end{array}$ & $\begin{array}{c}\text { Tinggi } \\
(2,5-3,0)\end{array}$ & Total \\
\hline Rendah $(70-863,3)$ & 25 & 0 & 0 & 25 \\
Sedang $(863,3-656,7)$ & 0 & 4 & 0 & 4 \\
Tinggi $(1656,7-2450)$ & 0 & 0 & 1 & 1 \\
\hline Total & 25 & 4 & 1 & 30 \\
\hline Persentase $(\%)$ & 83,33 & 13,33 & 3,34 & 100 \\
\hline Nilai sig & & & & 0.000 \\
\hline
\end{tabular}

Sumber : Data primer diolah, 2017 
Hossaimah \& Subari. 2017

Tabel 9. Alih Fungsi Lahan Pertanian Berdasarkan Asal Lahan

\begin{tabular}{lcccc}
\hline \multicolumn{1}{c}{ Alih fungsi } & Warisan & Membeli & $\begin{array}{c}\text { Milik } \\
\text { pemerintah }\end{array}$ & Total \\
\hline Rendah (70-863,3) & 17 & 8 & 0 & 25 \\
Sedang (863,3-656,7) & 1 & 2 & 0 & 4 \\
Tinggi (1656,7-2450) & 0 & 0 & 1 & 1 \\
\hline Total & 18 & 10 & 2 & 30 \\
\hline Persentase (\%) & 60 & 33 & 7 & 100 \\
\hline Nilai sig & & & 0.001 \\
\hline
\end{tabular}

Sumber : Data primer diolah, 2017

Tabel 10. Alih Fungsi Lahan Pertanian Berdasarkan Pemecahan Lahan (orang)

\begin{tabular}{lccc}
\hline \multicolumn{1}{c}{ Alih fungsi } & Pewarisan & $\begin{array}{c}\text { Bukan } \\
\text { pewarisan }\end{array}$ & Total \\
\hline Rendah(70-863,3) & 12 & 13 & 25 \\
Sedang(863,3-656,7) & 0 & 4 & 4 \\
Tinggi (1656,7-2450) & 0 & 1 & 1 \\
\hline Total & 12 & 18 & 30 \\
\hline Persentase (\%) & 40 & 60 & 100 \\
\hline Nilai sig & & & 0,135 \\
\hline
\end{tabular}

Sumber : Data primer diolah, 2017

Tabel 11. Alih Fungsi Lahan Pertanian Berdasarkan Perubahan Perilaku (orang)

\begin{tabular}{lccr}
\hline \multicolumn{1}{c}{ Alih fungsi } & $\begin{array}{c}\text { Terdapat } \\
\text { perubahan }\end{array}$ & $\begin{array}{c}\text { Tidak terdapat } \\
\text { perubahan }\end{array}$ & Total \\
\hline Rendah(70-863,3) & 15 & 10 & 25 \\
Sedang(863,3-656,7) & 0 & 4 & 4 \\
Tinggi $(1656,7-2450)$ & 0 & 1 & 1 \\
\hline Total & 15 & 15 & 30 \\
\hline Persentase (\%) & 50 & 50 & 100 \\
\hline Nilai sig & & & 0,05 \\
\hline
\end{tabular}

Sumber : Data primer diolah, 2017

Tabel 12. Alih Fungsi Lahan Pertanian Berdasarkan Hubungan Pemilik (orang)

\begin{tabular}{lccc}
\hline \multicolumn{1}{c}{ Alih fungsi } & $\begin{array}{c}\text { Terdapat } \\
\text { hubungan }\end{array}$ & $\begin{array}{c}\text { Tidak terdapat } \\
\text { hubungan }\end{array}$ & Total \\
\hline Rendah(70-863,3) & 17 & 8 & 25 \\
Sedang(863,3-656,7) & 0 & 4 & 4 \\
Tinggi $(1656,7-2450)$ & 0 & 1 & 1 \\
\hline Total & 17 & 13 & 30 \\
\hline Persentase (\%) & 57 & 43 & 100 \\
\hline Nilai sig & & & 0,020 \\
\hline
\end{tabular}

Sumber : Data primer diolah, 2017 
Agrisaintifika

Jurnal Ilmu-Ilmu Pertanian

Vol. 1, No. 2, 2017

Hossaimah \& Subari. 2017

Tabel 13. Alih Fungsi Lahan Pertanian Berdasarkan Pengurusan Izin (orang)

\begin{tabular}{lccc}
\hline \multicolumn{1}{c}{ Alih fungsi } & Mengurus izin & $\begin{array}{c}\text { Tidak } \\
\text { mengurus izin }\end{array}$ & Total \\
\hline Rendah(70-863,3) & 17 & 8 & 25 \\
Sedang(863,3-656,7) & 0 & 4 & 4 \\
Tinggi $(1656,7-2450)$ & 0 & 1 & 1 \\
\hline Total & 17 & 13 & 30 \\
\hline Persentase (\%) & 57 & 43 & 100 \\
\hline Nilai sig & & & 0,020 \\
\hline
\end{tabular}

Sumber : Data primer diolah, 2017 